\title{
Effects of Fuel Ethanol Use on Fuel-Cycle Energy and Greenhouse Gas Emissions
}

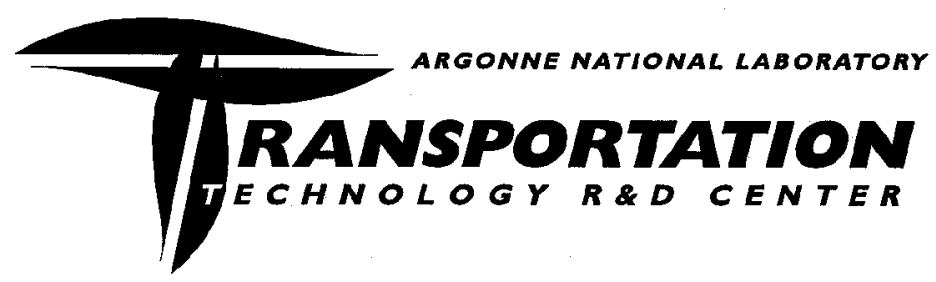

Center for Transportation Research Argonne National Laboratory

Operated by The University of Chicago, under Contract W-31-109-Eng-38, for the United States Department of Energy 


\section{Argonne National Laboratory}

Argonne National Laboratory, with facilities in the states of Illinois and Idaho, is owned by the United States Government, and operated by the University

of Chicago under the provisions of a contract with the Department of Energy.

This technical report is a product of Argonne's Energy Systems Division.

For information on the division's scientific and engineering activities, contact:

Director, Energy Systems Division

Argonne National Laboratory

Argonne, Illinois 60439-4815

Telephone (630) 252-3724

Publishing support services were provided by Argonne's Information and Publishing Division (for more information, see IPD's home page: http://www.ipd.anl.gov/).

\section{Disclaimer}

This report was prepared as an account of work sponsored by an agency of the United States Government. Neither the United States Government nor any agency thereof, nor any of their employees, makes any warranty, express or implied, or assumes any legal liability or responsibility for the accuracy, completeness, or usefulness of any information, apparatus, product, or process disclosed, or represents that its use would not infringe privately owned rights. Reference herein to any specific commercial product, process, or service by trade name, trademark, manufacturer, or otherwise, does not necessarily constitute or imply its endorsement, recommendation, or favoring by the United States Government or any agency thereof. The views and opinions of authors expressed herein do not necessarily state or reflect those of the United States Government or any agency thereof.

Reproduced directly from the best available copy.

Available to DOE and DOE contractors from the Office of Scientific and Technical Information, P.O. Box 62, Oak Ridge, TN 37831; prices available from (423) 576-8401.

Available to the public from the National Technical Information Service, U.S. Department of Commerce, 5285 Port Royal Road, Springfield, VA 22161. 


\section{Effects of Fuel Ethanol Use on Fuel-Cycle Energy and Greenhouse Gas Emissions}

by M. Wang, C. Saricks, and D. Santini

Center for Transportation Research, Energy Systems Division,

Argonne National Laboratory, 9700 South Cass Avenue, Argonne, Illinois 60439

January 1999

Work sponsored by U.S. Department of Energy,

Office of Technology Utilization,

Office of Transportation Technologies 


\section{Contents}

Notation.

V

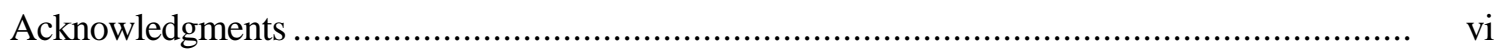

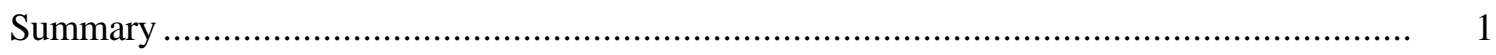

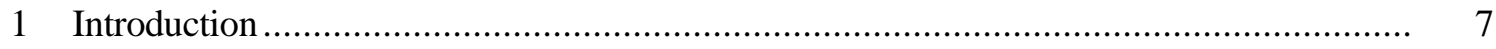

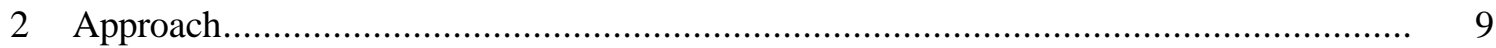

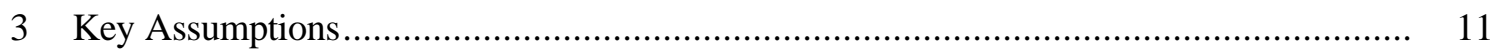

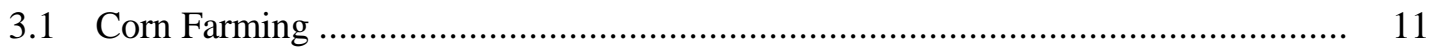

3.2 Potential Land Use Changes Caused by Corn Ethanol Production ........................ 11

3.3 Corn-Based Ethanol Production................................................................................. 13

3.4 Biomass Farming and Transportation ............................................................. 15

3.5 Production of Ethanol from Biomass ......................................................... 15

3.6 Ethanol Vehicle Fuel Economy ............................................................... 17

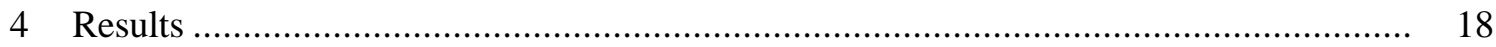

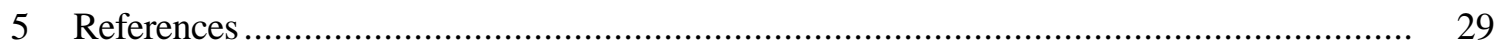

Figures

1 Corn/Biomass-to-Ethanol and Petroleum-to-Gasoline Fuel Cycles ............................ 10

2 Net Energy Balance per Gallon of Ethanol............................................................. 19

$3 \quad$ Fuel-Cycle Petroleum Use of Gasoline and Ethanol Blends by Stage ....................... 21

4 Fuel-Cycle Greenhouse Gas Emissions of Gasoline and Ethanol Blends by Stage ....... 22

5 Fuel-Cycle Greenhouse Gas Emissions of Gasoline and Ethanol Blends by Gas.......... 23

$6 \quad$ Fuel-Cycle Fossil Energy Use of Gasoline and Ethanol Blends by Stage ..................... 24

\section{Tables}

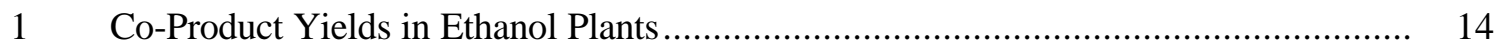

2 Co-Product Displacement Ratios ................................................................ 14 


\section{Tables (Cont.)}

3 Energy and Chemical Use for Biomass Farming and Transportation.........................

$4 \quad$ Feedstock Requirements, Energy Use, and Electricity Generation

Credits in Cellulosic Ethanol Plants ................................................................ 16

$5 \quad$ Parametric Assumptions for Current Case, Near-Future Case, and Future Case ......... 18

6 Reductions in per-Vehicle-Mile GHG Emissions and Energy Use

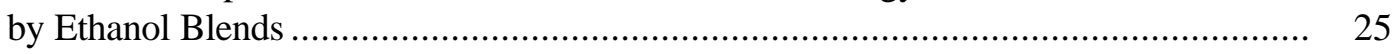

7 Sensitivity Analysis: Reductions in per-Vehicle-Mile GHG Emissions and

Energy Use by Ethanol Blends......................................................................... 26

8 Reductions in GHG Emissions and Energy Use per Gallon of Ethanol

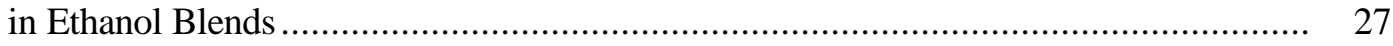

9 Sensitivity Analysis: Reductions in GHG Emissions and Energy Use per Gallon of Ethanol in Ethanol Blends ......................................................... 28 
Notation

\section{Acronyms}

CG conventional (non-reformulated) gasoline

$\mathrm{CH}_{4}$ methane

$\mathrm{CO}$ carbon monoxide

$\mathrm{CO}_{2} \quad$ carbon dioxide

CTR Center for Transportation Research

DGS distillers' grains and solubles

DOE U.S. Department of Energy

E10 $\quad 10 \%$ ethanol and $90 \%$ gasoline by volume

E85 $\quad 85 \%$ ethanol and $15 \%$ gasoline by volume

E95 $95 \%$ ethanol and $5 \%$ gasoline by volume

EPA U.S. Environmental Protection Agency

EtOH ethanol

FFV flexible-fueled vehicle

GHG greenhouse gas

GREET Greenhouse gases, Regulated Emissions, and Energy use in Transportation

GWP global warming potential

$\mathrm{K}_{2} \mathrm{O}$ potash

$\mathrm{N}_{2} \mathrm{O} \quad$ nitrous oxide

$\mathrm{NO}_{\mathrm{x}} \quad$ oxides of nitrogen

NREL National Renewable Energy Laboratory

$\mathrm{P}_{2} \mathrm{O}_{5} \quad$ phosphate

$\mathrm{PM}_{10} \quad$ particulate matter with size equal to or smaller than 10 microns

$\mathrm{R} \& \mathrm{D} \quad$ research and development

$\mathrm{SO}_{\mathrm{x}} \quad$ oxides of sulfur

USDA U.S. Department of Agriculture

VOC volatile organic compound

\section{Units of Measure}

$\begin{array}{ll}\text { Btu } & \text { British thermal unit } \\ \mathrm{bu} & \text { bushel } \\ \mathrm{g} & \text { gram } \\ \mathrm{gal} & \text { gallon } \\ \mathrm{kWh} & \text { kilowatt hour } \\ \mathrm{lb} & \text { pound } \\ \mathrm{mi} & \text { mile } \\ \mathrm{yr} & \text { year }\end{array}$




\section{Acknowledgments}

The Office of Technology Utilization and the Office of Transportation Technologies of the U.S. Department of Energy (DOE) provided funding for this study. This work has been reviewed by the U.S. Department of Agriculture's (USDA's) Office of Energy Policy and New Uses and the U.S. Environmental Protection Agency's (EPA's) Office of Mobile Sources. We would like to thank DOE sponsors Paul McArdle and David Rodgers for their technical guidance. We would also like to express our appreciation to Debby Adler of EPA, Larry Berger of the University of Illinois at Urbana-Champaign, Jim Duffield of the USDA's Office of Energy Policy and New Uses, Michael Graboski of the Colorado School of Mines, Terry Klopfenstein of the University of Nebraska, David Loos of the Illinois Department of Commerce and Community Affairs, Phil Madson of Rapheal Katzen International Associates, Hosein Shapouri of the USDA's Office of Energy Policy and New Uses, Alan Trenkle of Iowa State University, Marie Walsh of Oak Ridge National Laboratory, and Bob Wooley of the National Renewable Energy Laboratory for their input and comments. We also appreciate the efforts of Mary Fitzpatrick of Argonne's Information and Publishing Division in editing this report. We are solely responsible for the input assumptions used and the results documented in this study.

The submitted manuscript has been authored by a contractor of the U.S. Government under contract no. W-31-109-ENG-38. Accordingly, the U.S. Government retains a nonexclusive, royalty-free license to publish or reproduce the published form of this contribution, or allow others to do so, for U.S. Government purposes. 


\section{Summary}

We estimated the effects on per-vehicle-mile fuel-cycle petroleum use, greenhouse gas (GHG) emissions, and energy use of using ethanol blended with gasoline in a mid-size passenger car, compared with the effects of using gasoline in the same car. Our analysis includes petroleum use, energy use, and emissions associated with chemicals manufacturing, farming of corn and biomass, ethanol production, and ethanol combustion for ethanol; and petroleum use, energy use, and emissions associated with petroleum recovery, petroleum refining, and gasoline combustion for gasoline. For corn-based ethanol, the key factors in determining energy and emissions impacts include energy and chemical usage intensity of corn farming, energy intensity of the ethanol plant, and the method used to estimate energy and emissions credits for co-products of corn ethanol. The key factors in determining the impacts of cellulosic ethanol are energy and chemical usage intensity of biomass farming, ethanol yield per dry ton of biomass, and electricity credits in cellulosic ethanol plants. The results of our fuel-cycle analysis for fuel ethanol are listed below. Note that, in the first half of this summary, the reductions cited are per-vehicle-mile traveled using the specified ethanol/gasoline blend instead of conventional (not reformulated) gasoline. The second half of the summary presents estimated changes per gallon of ethanol used in ethanol blends. GHG emissions are global warming potential (GWP)-weighted, carbon dioxide $\left(\mathrm{CO}_{2}\right)$ equivalent emissions of $\mathrm{CO}_{2}$, methane $\left(\mathrm{CH}_{4}\right)$, and nitrous oxide $\left(\mathrm{N}_{2} \mathrm{O}\right)$.

\section{Results: per Vehicle Mile Traveled with Ethanol Blends}

\section{Current Corn and Ethanol Production Case for Corn-Based Ethanol}

Use of E10 (10\% ethanol and 90\% gasoline by volume) achieves:

- $6 \%$ reduction in petroleum use,

- $1 \%$ reduction in GHG emissions, and

- $3 \%$ reduction in fossil energy use.

Use of E85 (85\% ethanol and 15\% gasoline by volume) achieves:

- $73-75 \%$ reduction in petroleum use,

- $14-19 \%$ reduction in GHG emissions, and

- 34-35\% reduction in fossil energy use.

Use of E95 (95\% ethanol and 5\% gasoline by volume) achieves:

- $85-88 \%$ reduction in petroleum use,

- $19-25 \%$ reduction in GHG emissions, and

- $42-44 \%$ reduction in fossil energy use. 
The range of the reductions for E85 and E95 reflects dry and wet milling ethanol production technologies; wet milling achieves smaller reductions than dry milling.

Near-Future Corn and Ethanol Production Case (around Year 2005) for Corn-Based Ethanol

Use of E10 achieves:

- $6 \%$ reduction in petroleum use,

- $2 \%$ reduction in GHG emissions, and

- $3 \%$ reduction in fossil energy use.

Use of E85 achieves:

- $74-76 \%$ reduction in petroleum use,

- 24-26\% reduction in GHG emissions, and

- $41-43 \%$ reduction in fossil energy use.

Use of E95 achieves:

- $86-88 \%$ reduction in petroleum use,

- 30-32\% reduction in GHG emissions, and

- $51-49 \%$ reduction in fossil energy use.

Again, the range of the reductions for E85 and E95 reflects dry and wet milling ethanol production technologies; wet milling achieves smaller reductions than dry milling.

Near-Future Cellulosic Ethanol Production Case

Use of E10 achieves:

- $6 \%$ reduction in petroleum use,

- 6-9\% reduction in GHG emissions, and

- $6-7 \%$ reduction in fossil energy use.

Use of E85 achieves:

- $70-71 \%$ reduction in petroleum use,

- $68-102 \%$ reduction in GHG emissions, and

- 70-79\% reduction in fossil energy use.

Use of E95 achieves:

- $81-84 \%$ reduction in petroleum use,

- 79-118\% reduction in GHG emissions, and

- $82-92 \%$ reduction in fossil energy use. 
The range of the reductions reflects cellulosic ethanol production from woody and herbaceous biomass; cellulosic ethanol derived from herbaceous biomass achieves smaller reductions in GHG emissions and fossil energy use but greater reductions in petroleum use than does ethanol from woody biomass.

Future Celullosic Ethanol Production Case (around Year 2010)

Use of E10 achieves:

- $7 \%$ reduction in petroleum use,

- 8-10\% reduction in GHG emissions, and

- $8-9 \%$ reduction in fossil energy use.

Use of E85 achieves:

- $71-73 \%$ reduction in petroleum use,

- $68-91 \%$ reduction in GHG emissions, and

- $71-75 \%$ reduction in fossil energy use.

Use of E95 achieves:

- $83-85 \%$ reduction in petroleum use,

- $79-105 \%$ reduction in GHG emissions, and

- $82-86 \%$ reduction in fossil energy use.

Again, the range of the reductions reflects cellulosic ethanol production from woody and herbaceous biomass; cellulosic ethanol derived from herbaceous biomass achieves smaller reductions in GHG emissions and fossil energy use but greater reductions in petroleum use than does ethanol from woody biomass.

The increased energy and emissions reduction benefits from E10 to E85 to E95 are attributable to two effects: use of more ethanol in blends and improvements in vehicle fuel economy from E10 to E85 to E95. The greater-than-100\% reductions in GHG emissions for woody cellulosic ethanol are attributable to the elimination of emissions from electric power plants. Electricity generated in cellulosic ethanol plants, because of the plant design, exceeds the internal needs of the plant. The excess is exported to the electric grid, reducing emissions from other generators of electricity.

Some researchers have suggested that, if cellulosic ethanol production technologies are improved significantly in the future, cellulosic ethanol produced from woody and/or herbaceous biomass could displace a large portion of the gasoline used for transportation in the United States. If these improvements are made, our study shows that a transition from corn ethanol to cellulosic ethanol would achieve much greater energy and GHG emissions reduction benefits than would use of corn ethanol alone. 
The results listed above are for each of the ethanol blends. The effect of using one gallon of neat (pure) ethanol in E10, E85, or E95 (and driving on each fuel until the gallon of ethanol is fully combusted) may be significant. For evaluating a policy of promoting ethanol fuel use, policy makers may be more interested in the overall effects of using ethanol regardless of the form in which it is used. One alternative to estimating the per-mile results for ethanol blends is estimating the petroleum, emissions, and energy effects per gallon of ethanol blended into E10, E85, and E95. The following are fuel-cycle energy and GHG emissions impacts associated with the use of a gallon of ethanol in each blend.

\section{Results: per Gallon of Ethanol Used}

\section{Current Corn and Ethanol Production Case for Corn-Based Ethanol}

Use of ethanol in E10 achieves:

- $90-93 \%$ reduction in petroleum use,

- $12-19 \%$ reduction in GHG emissions, and

- $40 \%$ reduction in fossil energy use.

Use of ethanol in E85 achieves:

- $92-95 \%$ reduction in petroleum use,

- $17-24 \%$ reduction in GHG emissions, and

- $44 \%$ reduction in fossil energy use.

Use of ethanol in E95 achieves:

- $92-95 \%$ reduction in petroleum use,

- $21-27 \%$ reduction in GHG emissions, and

- $46 \%$ reduction in fossil energy use.

The range of the reductions for ethanol in E85 and E95 reflects dry and wet milling ethanol production technologies; wet milling achieves smaller reductions than dry milling.

Near-Future Corn and Ethanol Production Case for Corn-Based Ethanol

Use of ethanol in E10 achieves:

- $91-94 \%$ reduction in petroleum use,

- $24-26 \%$ reduction in GHG emissions, and

- $46-49 \%$ reduction in fossil energy use. 
Use of ethanol in E85 achieves:

- $94-96 \%$ reduction in petroleum use,

- 30-32\% reduction in GHG emissions, and

- $54-52 \%$ reduction in fossil energy use.

Use of ethanol in E95 achieves:

- $93-95 \%$ reduction in petroleum use,

- 33-35\% reduction in GHG emissions, and

- 53-55\% reduction in fossil energy use.

Again, the range of the reductions for ethanol in E85 and E95 reflects dry and wet milling ethanol production technologies; wet milling achieves smaller reductions than dry milling.

Near-Future Cellulosic Ethanol Production Case

Use of ethanol in E10 achieves:

- $86-88 \%$ reduction in petroleum use,

- $84-131 \%$ reduction in GHG emissions, and

- $87-98 \%$ reduction in fossil energy use.

Use of ethanol in E85 achieves:

- $88-91 \%$ reduction in petroleum use,

- 86-130\% reduction in GHG emissions, and

- 89-100\% reduction in fossil energy use.

Use of ethanol in E95 achieves:

- 90-88\% reduction in petroleum use,

- 86-128\% reduction in GHG emissions, and

- 89-99\% reduction in fossil energy use.

The range of the reductions reflects cellulosic ethanol production from woody and herbaceous biomass; cellulosic ethanol derived from herbaceous biomass achieves smaller reductions in GHG emissions and fossil energy use but greater reductions in petroleum use than does ethanol from woody biomass. 
Future Cellulosic Ethanol Production Case

Use of ethanol in E10 achieves:

- $106-108 \%$ reduction in petroleum use,

- 112-144\% reduction in GHG emissions, and

- $120-126 \%$ reduction in fossil energy use.

Use of ethanol in E85 achieves:

- $90-92 \%$ reduction in petroleum use,

- 86-115\% reduction in GHG emissions, and

- 90-95\% reduction in fossil energy use.

Use of ethanol in E95 achieves:

- 90-92\% reduction in petroleum use,

- 85-114\% reduction in GHG emissions, and

- 89-94\% reduction in fossil energy use.

Again, the range of the reductions reflects cellulosic ethanol production from woody and herbaceous biomass; cellulosic ethanol derived from herbaceous biomass achieves smaller reductions in GHG emissions and fossil energy use but greater reductions in petroleum use than does ethanol from woody biomass.

As these results show, use of a unit of ethanol, regardless of the blend mix, achieves large petroleum use and GHG emissions benefits. Slight enhancements of the benefits have been estimated for the more efficient vehicle/fuel technologies using E85 and E95.

We tested two sensitivity cases. In one case, we used the market-value-based method in place of the displacement method in estimating energy and emissions credits for the co-products of corn ethanol. In the other case, we assumed that half of the electricity credit from cellulosic ethanol plants is used to displace electricity generation in electric power plants and the other half is used to meet the increased demand for electricity caused by electricity generation in cellulosic ethanol plants. In the first case, energy and emissions reduction benefits of corn ethanol increased somewhat. In the second case, energy and emissions reduction benefits of cellulosic ethanol were somewhat reduced.

The numbers presented are best estimates of average gains for the cases examined. Actual results for individual facilities will depend on many factors specific to the ethanol plant technologies used and the corn or cellulosic production methods. In the case of future cellulosic ethanol, the local mix of power plants and electricity displaced will also have an effect. Still another factor that will vary is the quality of the crude oil feedstock in the gasoline to which ethanol is compared. 


\section{Section 1 Introduction}

Concern about potential global warming effects of major greenhouse gases (GHGs) has led to recognition of the need to reduce anthropogenic GHG emissions worldwide. At the Kyoto Conference held in December 1997 in Kyoto, Japan, the United States provisionally committed to reduce its GHG emissions by $7 \%$ by around 2012, relative to its $1990 \mathrm{GHG}$ emissions level. Under a business-as-usual case, the GHG emissions from the U.S. transportation sector, which account for $29 \%$ of the nation's total GHG emissions (U.S. Environmental Protection Agency [EPA] 1998), will continue to increase because the number of vehicle miles traveled will rise. Substantial reductions in U.S. transportation GHG emissions per vehicle mile traveled will be necessary to achieve the Kyoto goal.

Using ethanol to fuel motor vehicles helps reduce GHG emissions. Fuel ethanol that is produced from corn has been used in gasohol or oxygenated fuels in the United States since the early 1980s. These gasoline fuels contain ethanol at concentrations of up to $10 \%$ by volume. As a result, the U.S. transportation sector now consumes about 1.2 billion gal of ethanol annually in this form, about $1 \%$ of U.S. total consumption of gasoline. Recently, domestic automakers have announced plans to produce a significant number of flexible-fueled vehicles (FFVs) that can use an ethanol blend - E85 (85\% ethanol and 15\% gasoline by volume) - alone or in any combination with gasoline. The addition of a significant number of such vehicles to the U.S. vehicle fleet would significantly increase the potential future market for fuel ethanol.

Although research and development (R\&D) efforts have been undertaken to develop and commercialize cellulosic ethanol technologies, for the next several years, ethanol will continue to be produced in the United States almost exclusively from corn. Until very recently, researchers believed that using ethanol in motor vehicles to replace petroleum-based gasoline caused net increases in GHG emissions and fossil energy use (Wang et al. 1997). The Center for Transportation Research (CTR) at Argonne National Laboratory (Argonne) has been conducting analyses of fuel-cycle energy and emissions impacts of various alternative transportation fuels, including corn ethanol. A recent CTR analysis found that prior studies indicating increases in GHG emissions resulting from the use of corn ethanol were no longer accurate because these studies employed relatively old data (Wang et al. 1997). The CTR research revealed that, when more current data are employed, estimates of these emissions actually decrease. This change is caused mainly by the increased productivity of U.S. corn farming in the last 15 years and the decrease in energy use at ethanol plants. Nonetheless, the magnitude of GHG emissions reductions associated with ethanol use is still subject to debate, mainly because two key issues remain unsettled: (1) where and how much additional land will be required to produce the corn needed for additional ethanol production? (2) how should analysts account for co-products from ethanol production plants? In this paper we approach these two issues armed with newly collected data, obtained by revising CTR's Greenhouse gases, Regulated Emissions, and Energy use in Transportation (GREET) model's estimate of fuel-cycle GHG emissions and energy impacts of fuel ethanol. 
Some researchers have suggested that, in the long run, cellulosic ethanol that is produced from woody and herbaceous biomass could displace a large portion of the gasoline consumption associated with the U.S. transportation sector, if cellulosic ethanol production technologies are improved significantly. To accurately compare corn and cellulosic ethanol with respect to petroleum use, GHG emissions, and energy use, we include cellulosic ethanol in this analysis. 


\section{Section 2 Approach}

We conducted a comparative analysis of fuel-cycle petroleum use, energy use, and GHG emissions of fuel ethanol relative to those of conventional gasoline (CG). Our fuel-cycle analysis includes all production, combustion, and transportation stages - from feedstock recovery to vehicular fuel combustion - for both ethanol and gasoline (Figure 1).

We used the GREET model to conduct our analysis. GREET calculates Btu-per-mile $(\mathrm{Btu} / \mathrm{mi})$ petroleum use, energy use, and gram-per-mile $(\mathrm{g} / \mathrm{mi})$ emissions by taking into account energy use (by fuel type) and emissions of fuel combustion and non-combustion emissions sources such as fuel leaks and evaporation (Wang 1996). The model contains various conventional and alternative transportation fuels including corn ethanol, cellulosic ethanol, and gasoline fuel cycles. It calculates total energy use (all energy sources), fossil energy use (petroleum, natural gas, and coal), and petroleum use. The model includes emissions of three major GHGs: carbon dioxide $\left(\mathrm{CO}_{2}\right)$, methane $\left(\mathrm{CH}_{4}\right)$, and nitrous oxide $\left(\mathrm{N}_{2} \mathrm{O}\right)$. These three gases were specified in the 1997 Kyoto Protocol of GHG emissions to be reduced by developed countries. We examined GREET's estimates of petroleum use, emissions of these GHGs, and fossil energy use for ethanol and gasoline. (The model also calculates emissions of five criteria pollutants: volatile organic compounds [VOCs], carbon monoxide [CO], nitrogen oxides $\left[\mathrm{NO}_{\mathrm{x}}\right]$, particulate matter with a diameter of less than 10 microns $\left[\mathrm{PM}_{10}\right]$, and sulfur oxides [ $\left.\mathrm{SO}_{\mathrm{x}}\right]$. For the criteria pollutants, which are a localized rather than a global problem, emissions are divided into "urban" and "total" emissions. Urban refers to the portion of the fuel-cycle emissions that occurs within the metropolitan area where the fuel is used. In this study, we did not consider criteria pollutant emissions.) 


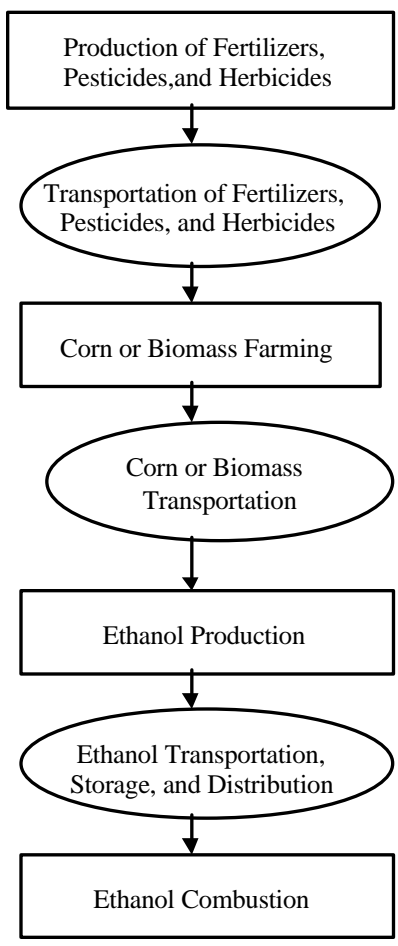

Corn- or Biomass-to-Ethanol Fuel Cycle

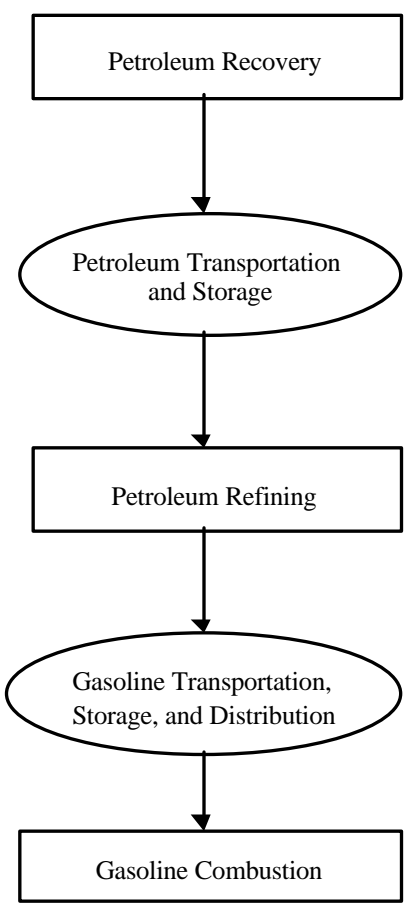

Petroleum-to-Gasoline Fuel Cycle

Figure 1 Corn/Biomass-to-Ethanol and Petroleum-to-Gasoline Fuel Cycles 


\section{Section 3 Key Assumptions}

In order to calculate fuel-cycle emissions and energy use, we must make certain assumptions regarding energy usage and emissions for each upstream stage. We documented our upstream assumptions regarding corn-based ethanol in a separate report (Wang et al. 1997). In that report we estimated emissions and energy impacts of ethanol produced from U.S. Midwest corn. In the present study, we estimated impacts of ethanol produced from U.S. corn, which includes Midwest corn.

\subsection{Corn Farming}

U.S. corn yield per acre has increased over the last 30 years by over $50 \%$, to about 125 bushel (bu) per harvested acre, thanks to better corn varieties, improved farming practices, and farming conservation measures. The yield has increased despite the fact that per-acre fertilizer and energy inputs for corn farming have stabilized or declined slightly over the last 15 years. A recent U.S. Department of Agriculture (USDA) simulation on crop farming projected that corn yield will continue to increase at about $1.2-1.3 \%$ annually per harvested acre from now to 2010 (Price et al. 1998).

Thus, energy and chemical usage intensity (in Btu/bu and g/bu of corn harvested) has decreased in the last 30 years, and is anticipated to decrease for some time into the future. Using corn farming data for sixteen major corn-growing states, we estimated that in 1996 (an average year in terms of weather and corn yield), the energy and chemical usage intensity for U.S. corn farming was 21,100 Btu of farming fuels, $489 \mathrm{~g}$ of nitrogen fertilizer, $184 \mathrm{~g}$ of phosphate fertilizer, and $220 \mathrm{~g}$ of potash fertilizer per bushel of corn harvested. We used these rates for our current case, and reduced each of them uniformly by $10 \%$ to approximate usage intensities for our near-future case (year 2005).

As shown above, a large amount of nitrogen fertilizer is used for corn farming. Some of the nitrogen in nitrogen fertilizer applied to cornfields eventually becomes $\mathrm{N}_{2} \mathrm{O}$ emissions either by emissions directly from the soil or from runoff water; both kinds of emissions are caused by nitrification and denitrification processes. Past studies showed large variations in $\mathrm{N}_{2} \mathrm{O}$ emissions from these sources. On the basis of a detailed review of studies for U.S. cornfields, Wang et al. (1997) concluded that about $1.5 \%$ of the nitrogen in nitrogen fertilizer applied to cornfields is released as nitrogen in $\mathrm{N}_{2} \mathrm{O}$ emissions to the atmosphere. We adopted this value for our study.

\subsection{Potential Land Use Changes Caused by Corn Ethanol Production}

The U.S. now produces annually about 1.5 billion gal of corn ethanol - a total that consumes about $6 \%$ of annual domestic corn production. A substantial increase in ethanol production will require a larger amount of corn available for ethanol production. The additional corn could come from (1) increased corn production through increased yield per acre; 
(2) reduced U.S. corn and corn product exports to other countries; (3) reduced corn consumption by other U.S. domestic sources of demand (such as for animal feeds); (4) farming on idled cropland and/or pastureland; and/or (5) switching cropland from other crops such as soybeans to corn. Increased yield per acre could be accomplished by genetic engineering of corn and/or by adoption of more efficient farming methods, currently described as "precision farming." If land use patterns are changed by increased ethanol production, a different profile of $\mathrm{CO}_{2}$ emissions can be expected. Biomass production per unit of land area is generally different for different crops and vegetation. Growing different crops and vegetation can also change the carbon content of land.

To estimate potential land use changes, the USDA's Office of Energy Policy and New Uses simulated the changes in production and consumption of major crops that would be caused by a selected, presumed change in corn ethanol production (Price et al. 1998). The USDA's simulation was based on complex supply and demand linkages in the agricultural sector, and included price effects that would result from diverting the specified amount of corn to ethanol and ethanol coproduct production. The simulation was conducted on the basis of an assumption that the amount of corn used for ethanol production would increase by 50 million bu/yr beginning in 1998. In the study, the corn increment to be diverted to ethanol production was 650 million bu/yr by 2010, a demand that would double ethanol production to over 3 billion gal/yr.

The USDA's simulation included changes in acres planted for corn, sorghum, barley, oats, wheat, soybeans, rice, and cotton. The simulation results showed a net increase in planted land of 97,400 acres, on average, between 1998 and 2010. In our analysis, we assumed that these additional planted acres are from idled crop and/or pastureland (USDA's simulations did not identify the source for the additional acreage). Delucchi (1998) estimated a $\mathrm{CO}_{2}$ emissions rate of $204,000 \mathrm{~g} / \mathrm{acre}$ for cornfields converted from idled cropland or pastureland. Thus, the total amount of $\mathrm{CO}_{2}$ emissions from the 97,400 acres of additional land is 20,000 metric tons/yr. The USDA's simulation assumed that an annual average of 350 million bu of corn would be converted to ethanol. On the basis of these data, we computed a domestic (U.S.) land use change $\mathrm{CO}_{2}$ emissions rate of $57 \mathrm{~g} / \mathrm{bu}$ of corn used in ethanol production.

The USDA simulation showed that increased U.S. ethanol production would reduce U.S. corn exports to other countries. On the basis of USDA simulation results, we estimated in our analysis that the net reduction in U.S. grain exports will be equivalent to about 694 million $\mathrm{lb}$ of protein a year. The USDA simulations did not include changes in crop supply and demand in grain-importing countries and grain-exporting countries other than the United States responding to the reduced U.S. grain exports. It is likely that grain-importing countries will experience increased costs for grain protein, which will reduce demand. These nations, together with other grain-exporting countries, will also likely increase their production in response to the higher prices caused by the reduced U.S. grain export. We had no basis for specifying how much of the 694-million-lb protein deficit could be made up by reduced demand in grain-importing countries and how much by increased production in both grain-importing and other grain-exporting countries. In our analysis, we simply assumed that farming new or currently idled land in those countries will make up half of the protein deficit. In other words, we assumed that increased planting makes up half of the import reduction and reduced consumer demand makes 
up the other half. By using this assumption, we estimated that grain-importing and other grainexporting countries will increase their own production by 347 million $\mathrm{lb}$ of grain-based protein in new lands per year - equivalent to 62.8 million bu of corn in protein equivalents.

We used corn production as a surrogate to calculate emissions of $\mathrm{CO}_{2}$ caused by the change in land use required to produce the 62.8 million bu of corn-equivalent protein. We assumed a corn yield of 110 bu per planted acre in grain-importing countries and other grain-exporting countries (by comparison, U.S. average corn yield is now about 120 and 125 bu per planted and harvested acre, respectively). We estimated that annual production of 62.8 million bu of corn would require a total of 570,900 acres of new land. We further assumed that the new land would be some type of pastureland. Using the $\mathrm{CO}_{2}$ emissions rate developed by Delucchi for a change from pastureland to cornfield (204,000 g/acre), we estimated a total $\mathrm{CO}_{2}$ emissions loading of 117,000 metric tons/yr. We allocated this amount to the 350 million bu of corn used annually for the new U.S. ethanol production. This calculation results in a rate of $333 \mathrm{~g}$ of $\mathrm{CO}_{2}$ emissions attributable to potential land use change in grain-importing countries and other grain-exporting countries per bushel of corn used in U.S. ethanol production.

In summary, we estimated a net $\mathrm{CO}_{2}$ emissions rate of $390(333+57) \mathrm{g} / \mathrm{bu}$ of corn from potential land use changes in both the United States and in grain-importing countries and other grain-exporting countries. Our fuel-cycle analysis showed that this amount of $\mathrm{CO}_{2}$ accounts for only about $1.5 \%$ of the total fuel-cycle GHG emissions associated with E85.

\subsection{Corn-Based Ethanol Production}

Energy Use for Ethanol Production. Ethanol plants are the largest fossil-energy-consuming component in the entire corn-to-ethanol fuel cycle. Ethanol production R\&D efforts in the last two decades have concentrated on increasing ethanol yield and reducing plant energy use. Newly built ethanol plants are generally more energy efficient than old plants. Energy use in older ethanol plants has also been reduced through integration of improved processes brought about by plant modifications and upgrades.

Both dry and wet milling ethanol plants were included in our analysis. We estimated fuelcycle energy use and emissions for the two types separately, trying to specify a representative plant for which ethanol production (rather than co-product production) is the main purpose. We collected information regarding recent trends in plant energy use from ethanol plant designers and operators in order to update estimates of total energy use. In a previous report (Wang et al. 1997), we estimated energy use rates of $41,400 \mathrm{Btu} / \mathrm{gal}$ of ethanol produced for a dry milling ethanol plant and 40,300 Btu/gal of ethanol produced for a wet milling plant. For near-term future ethanol plants (around 2005), given information obtained from designers and operators, we estimated that continuing improvements will result in an energy use rate of 36,900 Btu/gal for new dry milling plants and 34,000 Btu/gal for new wet milling plants. We assumed that expanded ethanol production needs will be met by these new plants.

Ethanol Co-Product Energy and Emissions Credits. While dry milling plants produce only ethanol and distillers' grains and solubles (DGS), wet mills produce corn gluten feed, corn gluten meal, and corn oil, together with ethanol. Most previous studies allocated emissions and 
energy use between ethanol and its co-products using one of four attribution methods for both corn farming and ethanol production: (1) product displacement, (2) market value, (3) energy content, or (4) weight (see Wang et al. 1997 for a discussion of each method).

In the present analysis, we used the displacement method to derive co-product energy and emissions credits. First, we estimated the amount of co-products produced in an ethanol plant. Second, we identified the products to be displaced by the co-products. Third, we determined displacement ratios between co-products and displaced products. Finally, we estimated emissions and energy use for producing the displaced products and subtracting the estimated emissions and energy use from those associated with corn farming and ethanol production. These steps are integral to the GREET model. Tables 1 and 2 present yields of co-products in ethanol plants and displacement ratios between co-products and the products they displace. The values were based on data provided during a workshop at Argonne National Laboratory by a group of experts on animal feeds (Berger 1998; Klopfenstein 1998; Madson 1998; Trenkle 1998).

Table 1 Co-Product Yields in Ethanol Plants

\begin{tabular}{|lc|}
\hline Co-Product & $\begin{array}{c}\text { Amount (bone-dry } \\
\text { Ib/bu of corn) }\end{array}$ \\
\hline Dry Milling & \\
DGS & \\
Wet Milling & 15.8 \\
Corn gluten meal & \\
Corn gluten feed & 2.6 \\
Corn oil & 11.2 \\
\end{tabular}

Table 2 Co-Product Displacement Ratios

\begin{tabular}{|lc|}
\hline Co-Product & $\begin{array}{c}\text { Ratio (lb of } \\
\text { displaced product/lb } \\
\text { of co-product) }\end{array}$ \\
\hline DGS & \\
Corn & \\
Soybean meal & 1.077 \\
Corn Gluten Meal & 0.823 \\
Corn & \\
Nitrogen in urea & 1.529 \\
Corn Gluten Feed & 0.023 \\
Corn & \\
Nitrogen in urea & 1.000 \\
Corn Oil & 0.015 \\
Soybean oil & 1.000 \\
\hline
\end{tabular}

The displacement ratios listed in Table 2 do not incorporate the effects of the price decrease of animal feeds caused by ethanol co-products. Additional co-product production from ethanol plants will likely lead to decreases in feed prices, which can in turn increase meat production. That is, of the total quantity of co-products produced in ethanol plants, some will displace the products currently used as animal feed and some will be employed in expanded production of meats. Using the USDA's simulation results (Price et al. 1998), we estimated that a $1 \%$ decrease in animal feed supply would result in a $0.151 \%$ decrease in meat production, implying that $15.1 \%$ of coproduct production could be used to produce additional meat. The small change in meat production caused by the change in feed supply is partly attributable to the fact that corn-based animal feed is usually used only for finish feeding of animals such as cattle and dairy cows. We did not account for the effects of co-products on expanded meat production when estimating emissions and energy credits for co-products because the co-products are used in new meat production rather than to displace animal feed for existing meat production. 


\subsection{Biomass Farming and Transportation}

Energy and Chemicals Use Intensities. R\&D efforts have been made to economically produce ethanol from fast-growing trees and grasses such as hybrid poplar and switchgrass. Table 3 presents energy and fertilizer/chemical use for biomass farming and transportation. The data were provided by Marie Walsh (1998) of Oak Ridge National Laboratory.

Table 3 Energy and Chemical Use for Biomass Farming and Transportation

\begin{tabular}{|lcc|}
\hline & $\begin{array}{c}\text { Woody Biomass } \\
\text { (hybrid poplar) }\end{array}$ & $\begin{array}{c}\text { Herbaceous Biomass } \\
\text { (switchgrass) }\end{array}$ \\
\hline Farming diesel use (Btu/dry ton) & 234,770 & 217,230 \\
Farming chemical use (g/dry ton) & 709 & 10,633 \\
Nitrogen fertilizer & 189 & 142 \\
Phosphate $\left(\mathrm{P}_{2} \mathrm{O}_{5}\right)$ fertilizer & 331 & 226 \\
Potash $\left(\mathrm{K}_{2} \mathrm{O}\right)$ fertilizer & 24 & 28 \\
Herbicides & 2 & 0 \\
Insecticides & 308,400 & 179,300 \\
Transportation energy use (Btu/dry ton) & & \\
\hline
\end{tabular}

$\mathrm{CO}_{2}$ Sequestration from Land Use Changes. No farms are currently growing and harvesting biomass to produce cellulosic ethanol in the manner specified in Table 3. If large-scale production of cellulosic ethanol occurs in the future, land will need to be cultivated for biomass farming. In the United States, some marginal land that is now idled and/or used for pastureland will likely be cultivated for biomass farming. Cultivating fast-growing trees and grasses such as hybrid popular and switchgrass on these lands will result in $\mathrm{CO}_{2}$ sequestration for three reasons: (1) the amount of aboveground standing biomass will be increased by biomass farming, (2) the amount of underground biomass (i.e., roots) will be increased, and (3) the organic carbon content of the soil will likely increase. Delucchi (1998) estimated that the $\mathrm{CO}_{2}$ sequestration rate caused by land use changes is $225,000 \mathrm{~g} / \mathrm{dry}$ ton of woody biomass and $97,000 \mathrm{~g} / \mathrm{dry}$ ton of grass harvested. We applied these sequestration rates in our analysis.

\subsection{Production of Ethanol from Biomass}

Feedstock and Energy Use. At cellulosic ethanol plants, the unfermentable biomass components, primarily lignin, can be used to generate steam (needed in ethanol plants) and electricity in cogeneration systems. Recent simulations of cellulosic ethanol production by National Renewable Energy Laboratory (NREL) indicated an ethanol yield of 76 gal per dry ton of hardwood biomass for ethanol plants that will be in operation around the year 2005 (Wooley 1998). Such ethanol plants consume 2,719 Btu of diesel fuel and generate 1.73 kilowatt hours $(\mathrm{kWh})$ of electricity per gallon of ethanol produced. For cellulosic ethanol plants operating in 2010, the simulations indicated an ethanol yield of 98 gal per dry ton of hardwood biomass. The plants will consume 2,719 Btu of diesel fuel and generate $0.56 \mathrm{kWh}$ of electricity per gallon of ethanol produced. Table 4 presents the assumptions used in our analysis. 
Table 4 Feedstock Requirements, Energy Use, and Electricity Generation Credits in Cellulosic Ethanol Plantsa

\begin{tabular}{|c|c|c|c|c|}
\hline & \multicolumn{2}{|c|}{ Woody Cellulosic Plant } & \multicolumn{2}{|c|}{$\begin{array}{c}\text { Herbaceous } \\
\text { Cellulosic Plant }^{b}\end{array}$} \\
\hline & $\begin{array}{c}\text { Near-Future } \\
(2005)\end{array}$ & $\begin{array}{l}\text { Future } \\
(2010)\end{array}$ & $\begin{array}{l}\text { Near-Future } \\
(2005)\end{array}$ & $\begin{array}{l}\text { Future } \\
(2010)\end{array}$ \\
\hline EtOH yield (gal/dry ton of biomass) & 76 & 98 & 80 & 103 \\
\hline Diesel use (Btu/gal of EtOH) & 2,719 & 2,719 & 2,719 & 2,719 \\
\hline Electricity credit (kWh/gal of EtOH) & 1.73 & 0.56 & 0.865 & 0.28 \\
\hline
\end{tabular}

a From Wooley (1998), except as noted.

b Values for herbaceous cellulosic plants were estimated from the values for woody cellulosic plants, as presented here, and the differences between woody and herbaceous plants that were estimated from data in NREL et al. (1991).

While combustion of lignin undoubtedly produces $\mathrm{CO}_{2}$ emissions, these emissions are taken up from the atmosphere by the photosynthesis process during biomass growth. Thus, $\mathrm{CO}_{2}$ emissions from lignin combustion at ethanol plants were treated as zero. For the same reason, $\mathrm{CO}_{2}$ emissions from ethanol combustion in ethanol vehicles were also treated as zero.

Energy Use and Emissions for Electricity Credits in Cellulosic Ethanol Plants. In cellulosic ethanol plants, combustion of lignin through co-generation facilities generates electricity and the steam required for ethanol production. Table 4 lists the credits for excess electricity generated by cellulosic ethanol plants; these credits were estimated on the basis of recent NREL simulations. We assumed that the excess electricity generated in cellulosic ethanol plants is exported to the electric supply grid to offset production by electric power plants. Emissions and energy credits for the generated electricity were therefore calculated by taking into account the amount of electricity generated by the cellulosic ethanol plant and deducting the emissions associated with the (estimated) amount of electricity that would otherwise have been generated by electric power plants.

Emissions and energy credits for the generated electricity are a key factor in determining fuel-cycle energy and emissions results for cellulosic ethanol. Calculation of the emissions and energy credits depends on the way in which the researchers address two key questions. First, of the total amount of electricity generated at cellulosic ethanol plants, how much will be used to displace electricity generated by electric power plants and how much will be used to meet the increased demand for electricity induced by cellulosic ethanol electricity through its price effect? We established a case in which only half of the generated electricity was considered for displacement of electricity generated by electric power plants, and the other half was used to meet the increased demand for electricity. Second, what electric power plants will be displaced by the electricity generated in cellulosic ethanol plants? Determining the marginal electric power plants to be displaced requires detailed simulation of future electricity supply in major U.S. regions. We assumed that cellulosic ethanol electricity will displace electric generation on the basis of the U.S. average generation mix. 


\subsection{Ethanol Vehicle Fuel Economy}

We assumed use of ethanol in a mid-size passenger car such as the Ford Taurus ethanol FFV. For our mid-size car, we assumed use of conventional (not reformulated) gasoline, E10, and E85. Dedicated ethanol vehicles, although not now available, may emerge in the future as ethanol refueling infrastructure becomes extensive and the cold-start problem with dedicated ethanol vehicles is solved. These vehicles offer greater emissions and energy benefits than FFVs, partly because the octane of ethanol is higher than that of gasoline. Higher octane allows a higher compression ratio, which makes the engine more thermally efficient. In an FFV, the engine compression ratio is limited by gasoline octane, although some on-board computer calibration can allow higher effective compression ratios when using E85. In our analysis, we included a midsize dedicated ethanol car to be fueled with E95. On the basis of the fuel economy test results for existing FFVs, we assumed that the gasoline-equivalent fuel economy of current E85 FFVs is 5\% higher than that of comparable gasoline vehicles. Note that the 1998 Ford FFV Taurus fueled with E85 achieves about a 5\% improvement in gasoline-equivalent fuel economy (Adler 1997). We assumed no difference in gasoline-equivalent fuel economy between gasoline and E10, but did assume a fuel economy improvement of $10 \%$ by dedicated E95 vehicles over gasoline vehicles. Table 5, provided in Section 4, lists our assumptions regarding fuel economy. 


\section{Section 4 Results}

We estimated fuel-cycle energy use and GHG emissions of conventional (not reformulated) gasoline, E10, E85, and E95, all in a mid-size car. Estimates were made for the following cases: (1) a current case with current technologies for production of ethanol from corn and for ethanol vehicles; (2) a near-future case (around 2005) with assumed improvements in corn ethanol production technologies, near-term cellulosic ethanol production technologies, and ethanol vehicle technologies; and (3) a future case (around 2010) with assumed improvements in cellulosic ethanol production technologies. Table 5 presents the three cases.

\section{Table 5 Parametric Assumptions for Current Case, Near-Future Case, and Future Case}

\begin{tabular}{|lccc|}
\hline & & Near-Future Case & Future Case \\
& Current Case & (2005) & (2010) \\
\hline Vehicle fuel economy & & & \\
CG (mpg) & 23 & 25 & 27 \\
E85 FFV (\% mpg increase) & $5 \%$ & $7 \%$ & $7 \%$ \\
E95-dedicated (\% mpg increase) & $10 \%$ & $12 \%$ & $12 \%$ \\
Corn ethanol plant yield & & 2.7 & $\mathrm{NN}^{\mathrm{a}}$ \\
Dry milling (gal/bu) & 2.6 & 2.6 & $\mathrm{NN}^{\mathrm{a}}$ \\
Wet milling (gal/bu) & 2.5 & & $\mathrm{NN}^{\mathrm{a}}$ \\
Corn ethanol plant energy use & & 36,900 & $\mathrm{NN}^{\mathrm{a}}$ \\
Dry milling (Btu/gal) & 41,400 & 34,000 & \\
Wet milling (Btu/gal) & 40,300 & & 98 \\
Cellulosic ethanol plant yield & & 76 & 103 \\
Woody biomass (gal/dry ton) & $\mathrm{NN}$ & \\
Herbaceous biomass (gal/dry ton) & $\mathrm{NN}$ & 80 & 0.56 \\
Cellulosic ethanol plant electricity credit & & & 0.28 \\
Woody biomass (kWh/gal) & $\mathrm{NN}$ & 1.73 & \\
Herbaceous biomass (kWh/gal) & $\mathrm{NN}^{\mathrm{a}}$ & 0.865 & \\
\hline
\end{tabular}

a Not needed; these cases were not evaluated.

Figure 2 presents the net energy balance for a gallon of ethanol produced. The balance was calculated by the energy contained in a gallon of ethanol (i.e., 76,000 Btu) minus the energy required to produce the gallon as estimated in this study. The energy requirement here includes energy in petroleum, natural gas, and coal - the three fossil energy sources. As the figure shows, corn-based ethanol has a net energy balance of 20,000-25,000 Btu per gallon, and cellulosic ethanol over 60,000 Btu per gallon. The positive net energy balance for corn ethanol is attributable to the improvements in corn farming and corn-to-ethanol conversion that have been achieved in the last 20 years. The large positive net energy balance for cellulosic ethanol is largely attributable to two factors: the fact that little fossil energy is used in biomass farming 


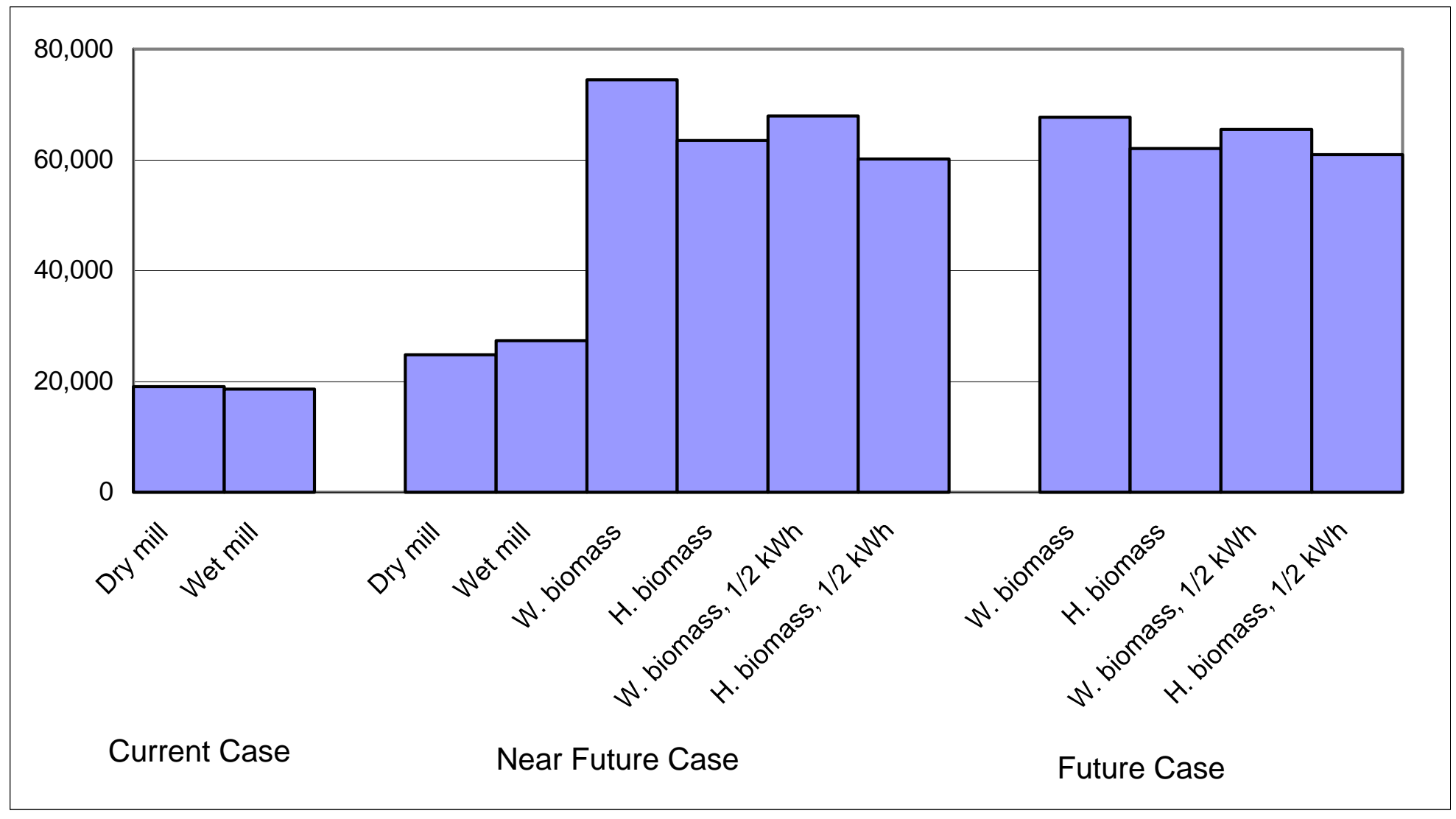

Figure 2 Net Energy Balance per Gallon of Ethanol (energy [in Btu] contained in one gallon of ethanol minus energy required to produce the gallon) 
and cellulosic ethanol conversion and, to a lesser extent, to the assumption that the extra electricity generated in cellulosic ethanol plants will be exported into the electric grid to displace electric generation in electric power plants. To test the magnitude of the electricity credit effect, a sensitivity case assuming that only half of the cellulosic electricity credit is used to displace electricity generation (the $1 / 2 \mathrm{kWh}$ case as shown in Figure 2) was modeled. Under this case, though reduced somewhat, the net energy balance of cellulosic ethanol is still above 60,000 Btu per gallon.

Figures 3 through 6 present and compare all the cases with respect to fuel-cycle energy use and GHG emissions by stage and by gas (for GHG emissions only). Figure 3 presents per-mile petroleum use results. As expected, as ethanol's share in ethanol and gasoline blends increases, petroleum reductions by blends increase substantially.

Most GHG emissions in the gasoline and E10 cycles occur during vehicle operation; GHG emissions in the E85 and E95 cycles occur during fuel production (Figure 4). The negative GHG emissions associated with the near-future case and future case for woody cellulosic ethanol are attributable to the electricity credits in woody cellulosic ethanol plants. Among the three GHGs, $\mathrm{CO}_{2}$ accounts for the majority of total emissions and net global warming effect (Figure 5). However, in the case of E85 and E95, emissions of $\mathrm{N}_{2} \mathrm{O}$ - because of its relatively high emissions level during corn farming and its high (310) global warming potential (GWP) account for a considerable proportion of the total estimated emissions of the three gases.

As Figure 6 shows, while most fossil energy consumption in the gasoline and E10 fuel cycles occurs in the vehicle operation stage, the majority of energy consumption in the E85 and E95 fuel cycles occurs in the fuel production stage. The use of ethanol results in reductions in fossil energy use. As the share of ethanol in ethanol blends increases, fossil energy use is reduced further. Note that in the near-future case for cellulosic ethanol from woody biomass, some negative fossil energy use is shown for the ethanol production stage. This is because of the fossil energy credit from the electricity produced in cellulosic ethanol plants.

We calculated per-vehicle-mile percentage changes in GHG emissions and energy use by E10, E85, and E95 relative to gasoline for each of the cases considered in this study (Table 6). As expected, the per-vehicle-mile reductions in fossil energy use, petroleum use, and GHG emissions are proportional to the ethanol share in ethanol blends. Also, relative improvements in gasoline-equivalent fuel economy from E10 to E85 to E95 contribute secondarily to the increased benefits of E85 and E95. For corn-based ethanol, in the current case, E85 achieves about a 73$75 \%$ reduction in petroleum use (depending on whether dry or wet milling is the production technology) and a 35\% reduction in fossil energy use. For GHG emissions, E85 produced by dry milling achieves a 19\% reduction, and E85 produced by wet milling achieves a 14\% reduction. Overall, wet milling technologies achieve fewer emissions and energy benefits than dry milling technologies because co-products of wet milling plants can claim lower total emissions and energy credits (the amount of emissions and energy use subtracted from ethanol fuel cycle emissions and energy use). In the near-future case, the emissions and energy benefits of new corn ethanol production increase with improvements in both wet and dry milling technologies. For example, new dry mills achieve a $26 \%$ reduction in GHG emissions and new wet mills a $24 \%$ reduction. 


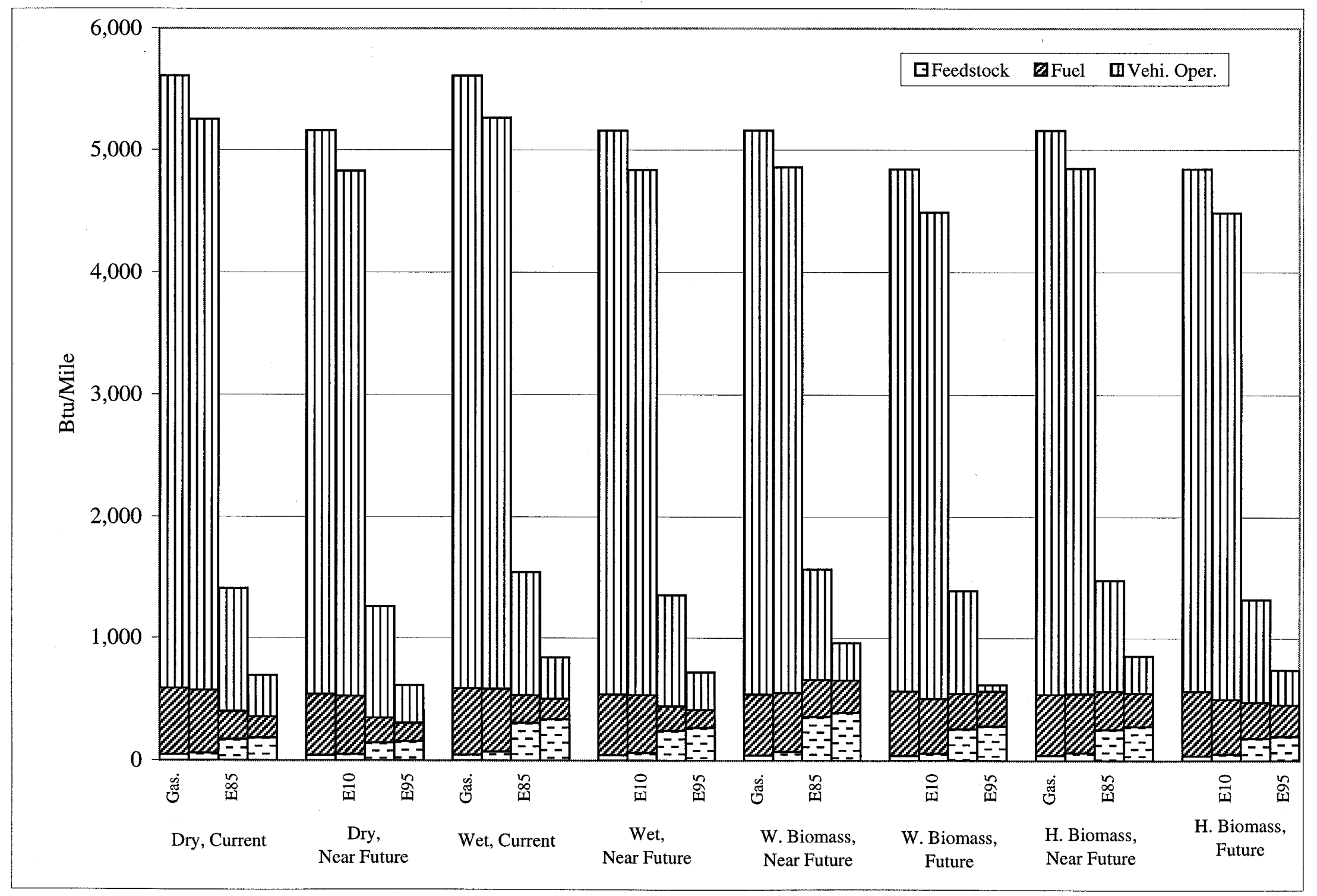

Figure 3 Fuel-Cycle Petroleum Use of Gasoline and Ethanol Blends by Stage 


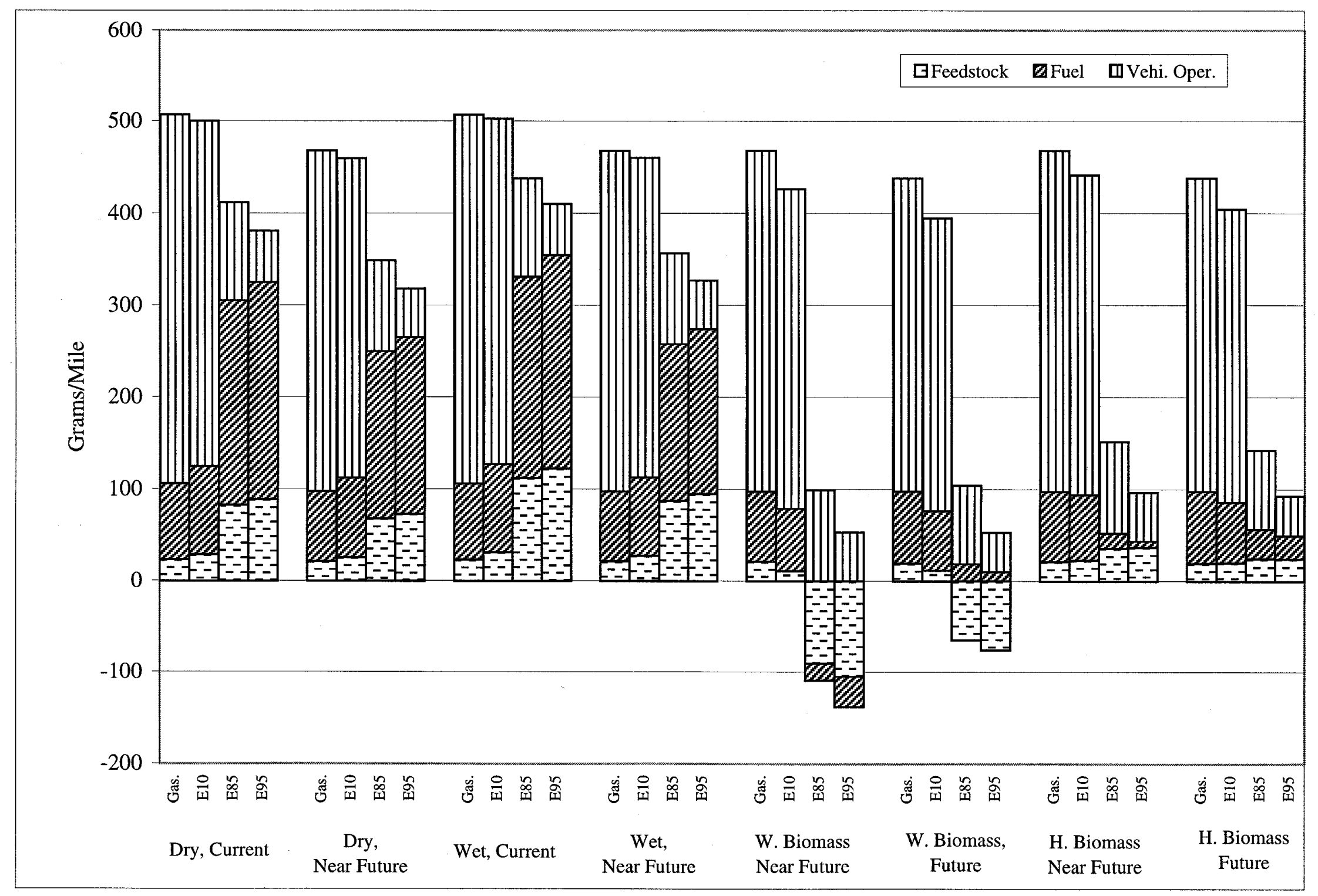

Figure 4 Fuel-Cycle Greenhouse Gas Emissions of Gasoline and Ethanol Blends by Stage 


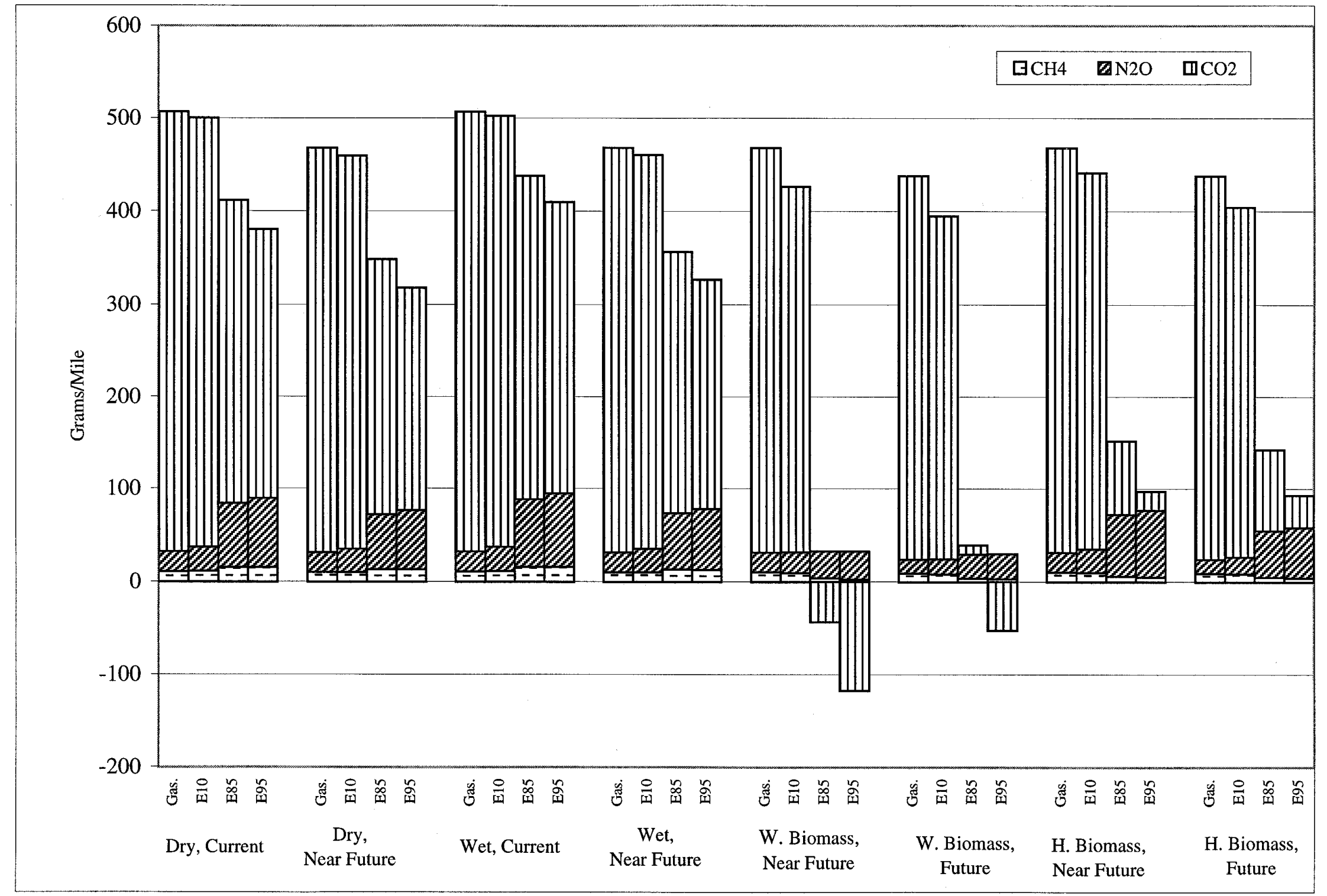

Figure 5 Fuel-Cycle Greenhouse Gas Emissions of Gasoline and Ethanol Blends by Gas 
$\Delta$

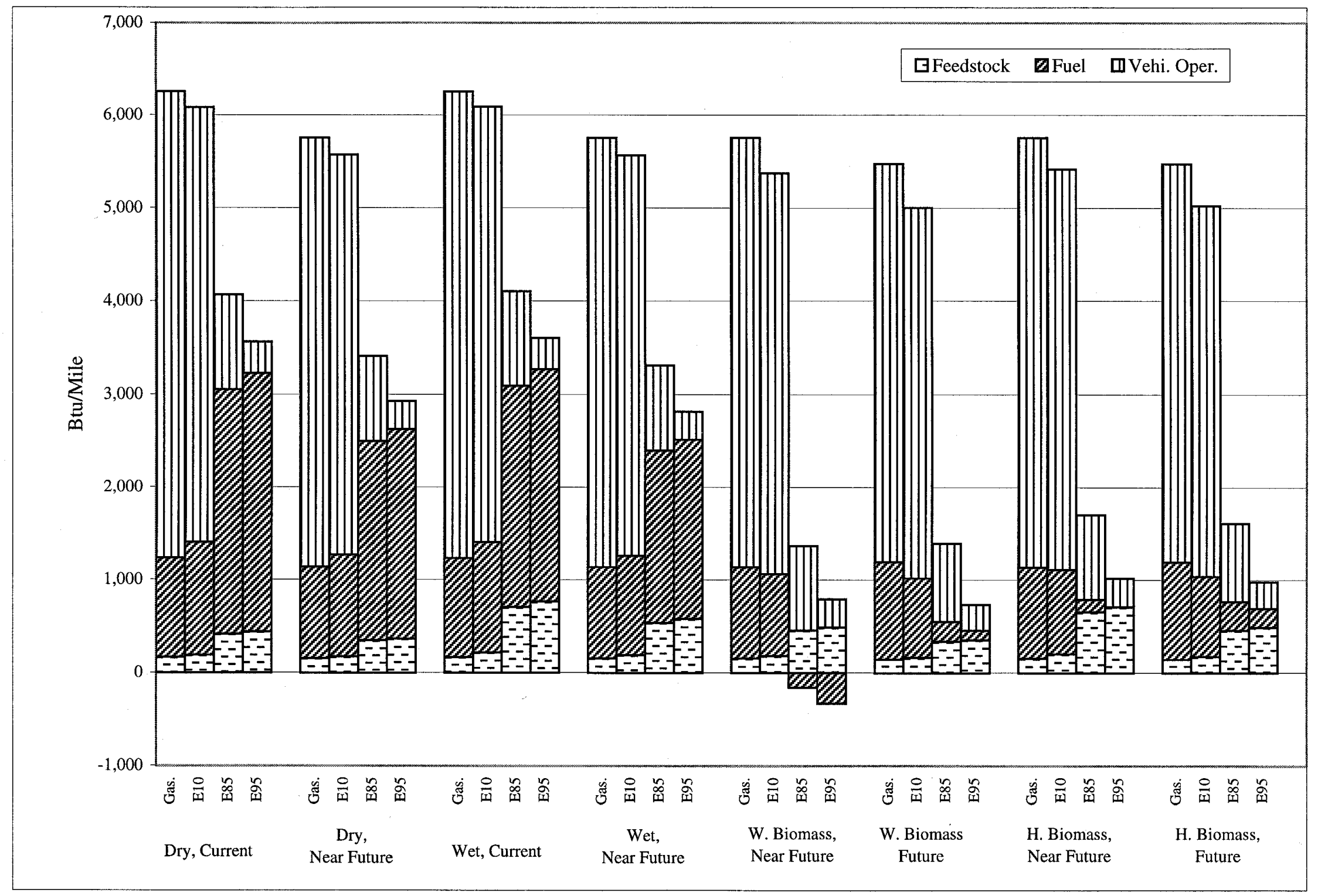

Figure 6 Fuel-Cycle Fossil Energy Use of Gasoline and Ethanol Blends by Stage 
Table 6 Reductions in per-Vehicle-Mile GHG Emissions and Energy Use by Ethanol Blends (percentage relative to emissions and energy use of gasoline)

\begin{tabular}{|c|c|c|c|c|c|c|}
\hline & E10 & E85 & E95 & E10 & E85 & E95 \\
\hline \multicolumn{7}{|c|}{ Corn-Based Ethanol: Current Case } \\
\hline & \multicolumn{3}{|c|}{ Dry Milling } & \multicolumn{3}{|c|}{ Wet Milling } \\
\hline Petroleum & $6.4 \%$ & $74.9 \%$ & $87.7 \%$ & $6.1 \%$ & $72.5 \%$ & $85.0 \%$ \\
\hline GHG emissions & $1.3 \%$ & $18.8 \%$ & $24.9 \%$ & $0.8 \%$ & $13.7 \%$ & $19.1 \%$ \\
\hline Fossil energy & $2.7 \%$ & $35.0 \%$ & $44.3 \%$ & $2.7 \%$ & $34.4 \%$ & $42.3 \%$ \\
\hline \multicolumn{7}{|c|}{ Corn-Based Ethanol: Near-Future Case } \\
\hline & \multicolumn{3}{|c|}{ Dry Milling } & \multicolumn{3}{|c|}{ Wet Milling } \\
\hline Petroleum & $6.4 \%$ & $75.6 \%$ & $88.1 \%$ & $6.2 \%$ & $73.7 \%$ & $86.1 \%$ \\
\hline GHG emissions & $1.8 \%$ & $25.5 \%$ & $32.0 \%$ & $1.6 \%$ & $23.8 \%$ & $30.1 \%$ \\
\hline Fossil energy & $3.2 \%$ & $40.7 \%$ & $49.1 \%$ & $3.3 \%$ & $42.5 \%$ & $51.0 \%$ \\
\hline \multicolumn{7}{|c|}{ Cellulosic Ethanol: Near-Future Case } \\
\hline & \multicolumn{3}{|c|}{ Woody Biomass } & \multicolumn{3}{|c|}{ Herbaceous Biomass } \\
\hline Petroleum & $5.8 \%$ & $69.6 \%$ & $81.4 \%$ & $6.0 \%$ & $71.4 \%$ & $83.5 \%$ \\
\hline GHG emissions & $8.9 \%$ & $102.2 \%$ & $118.2 \%$ & $5.7 \%$ & $67.6 \%$ & $79.3 \%$ \\
\hline Fossil energy & $6.7 \%$ & $79.0 \%$ & $92.0 \%$ & $5.9 \%$ & $70.4 \%$ & $82.3 \%$ \\
\hline \multicolumn{7}{|c|}{ Cellulosic Ethanol: Future Case } \\
\hline & \multicolumn{3}{|c|}{ Woody Biomass } & \multicolumn{3}{|c|}{ Herbaceous Biomass } \\
\hline Petroleum & $7.2 \%$ & $71.3 \%$ & $83.1 \%$ & $7.4 \%$ & $72.7 \%$ & $84.7 \%$ \\
\hline GHG emissions & $9.8 \%$ & $91.0 \%$ & $105.1 \%$ & $7.6 \%$ & $67.5 \%$ & $78.8 \%$ \\
\hline Fossil energy & $8.5 \%$ & $74.5 \%$ & $86.6 \%$ & $8.2 \%$ & $70.6 \%$ & $82.1 \%$ \\
\hline
\end{tabular}

Transition from corn ethanol to cellulosic ethanol achieves great GHG emissions and energy benefits. Under the near-future case, for E85, woody cellulosic ethanol reduces petroleum use by $70 \%$, GHG emissions by $102 \%$, and fossil energy consumption by $79 \%$. The greater- than- $100 \%$ reduction for GHG emissions is caused by GHG emissions offsets in electric power generation. The offsets are from the displacement (reduction) of utility-generated electric power that results from the sale of excess electric power generated by the woody biomass cellulosic ethanol technology. The specified herbaceous cellulosic ethanol production technology is estimated to reduce petroleum use by $71 \%$, GHG emissions by $68 \%$, and fossil energy consumption by $70 \%$. Under the future case, energy and GHG emissions benefits of woody cellulosic ethanol, though still substantial, are less than those for the near-future case because of the substantial reductions in electricity credits for future cellulosic ethanol plants (see Table 5). Energy and emissions benefits of herbaceous cellulosic ethanol are similar for the near-future and the future cases. Thus, improvements in ethanol yields in cellulosic ethanol plants over time, because they are accompanied by reduced electricity credits, do not result in greater emissions and energy benefits. However, the technological improvements will certainly help the economics of producing cellulosic ethanol.

Table 7 presents results for two sensitivity cases. For the first, the market-value-based approach is used to determine emissions and energy credits of corn ethanol co-products. For the second case, we assumed that half of the electricity generated in cellulosic ethanol plants is used 
to displace electricity generated by electric power plants and the other half is used to meet the increased demand for electricity. As the table shows, use of the market-value-based method slightly increases energy and GHG emissions benefits for ethanol produced by both dry and wet milling but slightly decreases petroleum use benefits. The increase for ethanol produced by wet milling is larger than that for ethanol produced by dry milling because the co-products from wet milling are more valuable than those for dry milling. The assumption of half of the electricity credits for displacement of electric generation reduces the GHG emissions and energy benefits of cellulosic ethanol, but this reduction is moderate.

Table 7 Sensitivity Analysis: Reductions in per-Vehicle-Mile GHG Emissions and Energy Use by Ethanol Blends (percentage relative to emissions and energy use of gasoline)

\begin{tabular}{|c|c|c|c|c|c|c|}
\hline & E10 & E85 & E95 & E10 & E85 & E95 \\
\hline \multicolumn{7}{|c|}{ Corn-Based Ethanol: Current Case, Market-Value-Based Method } \\
\hline & \multicolumn{3}{|c|}{ Dry Milling } & \multicolumn{3}{|c|}{ Wet Milling } \\
\hline Petroleum & $6.0 \%$ & $71.3 \%$ & $83.6 \%$ & $6.1 \%$ & $71.6 \%$ & $84.0 \%$ \\
\hline GHG emissions & $1.5 \%$ & $20.9 \%$ & $27.2 \%$ & $1.6 \%$ & $21.7 \%$ & $28.2 \%$ \\
\hline Fossil energy & $3.0 \%$ & $37.7 \%$ & $46.1 \%$ & $3.2 \%$ & $40.4 \%$ & $49.1 \%$ \\
\hline \multicolumn{7}{|c|}{ Corn-Based Ethanol: Near-Future Case, Market-Value-Based Method } \\
\hline & \multicolumn{3}{|c|}{ Dry Milling } & \multicolumn{3}{|c|}{ Wet Milling } \\
\hline Petroleum & $6.1 \%$ & $72.6 \%$ & $84.8 \%$ & $6.1 \%$ & $72.9 \%$ & $85.1 \%$ \\
\hline GHG emissions & $2.0 \%$ & $27.9 \%$ & $34.8 \%$ & $2.2 \%$ & $29.9 \%$ & $37.0 \%$ \\
\hline Fossil energy & $3.4 \%$ & $43.5 \%$ & $52.1 \%$ & $3.7 \%$ & $46.9 \%$ & $56.0 \%$ \\
\hline \multicolumn{7}{|c|}{ Cellulosic Ethanol: Near-Future Case, Half of Electricity Credit for Displacement Effect } \\
\hline & \multicolumn{3}{|c|}{ Woody Biomass } & \multicolumn{3}{|c|}{ Herbaceous Biomass } \\
\hline Petroleum & $5.8 \%$ & $69.4 \%$ & $81.2 \%$ & $6.0 \%$ & $71.3 \%$ & $83.4 \%$ \\
\hline GHG emissions & $8.3 \%$ & $95.7 \%$ & $110.9 \%$ & $5.4 \%$ & $64.3 \%$ & $75.6 \%$ \\
\hline Fossil energy & $6.2 \%$ & $73.8 \%$ & $86.2 \%$ & $5.7 \%$ & $67.8 \%$ & $79.4 \%$ \\
\hline \multicolumn{7}{|c|}{ Cellulosic Ethanol: Future Case, Half of Electricity Credit for Displacement Effect } \\
\hline & \multicolumn{3}{|c|}{ Woody Biomass } & \multicolumn{3}{|c|}{ Herbaceous Biomass } \\
\hline Petroleum & $7.2 \%$ & $71.2 \%$ & $83.1 \%$ & $7.4 \%$ & $72.7 \%$ & $84.7 \%$ \\
\hline GHG emissions & $9.6 \%$ & $89.0 \%$ & $102.9 \%$ & $7.5 \%$ & $66.5 \%$ & $77.7 \%$ \\
\hline Fossil energy & $8.4 \%$ & $72.8 \%$ & $84.7 \%$ & $8.1 \%$ & $69.7 \%$ & $81.2 \%$ \\
\hline
\end{tabular}

Tables 6 and 7 show the emissions and energy effects of using ethanol blends on a per-mile basis. In evaluating policies to promote ethanol fuel use, policymakers may be more interested in the effects of using one gallon of ethanol in E10, E85, or E95. Tables 8 and 9 present per-gallonof-ethanol GHG emissions and energy use associated with using E10, E85, or E95, combining both the effect of ethanol-to-gasoline Btu displacement and, for E85 and E95, the allowed improvements in the efficiency of the vehicles designed specifically to run on those fuels. The results in these two tables are derived from the results listed in Tables 6 and 7. In particular, emissions and energy use changes in Tables 6 and 7 were divided by $6.8 \%$ for E10, 78.9\% for E85, and $92.6 \%$ for E95 — the energy shares of ethanol in each of these blends. 


\begin{tabular}{|c|c|c|c|c|c|c|}
\hline & E10 & E85 & E95 & E10 & E85 & E95 \\
\hline \multicolumn{7}{|c|}{ Corn-Based Ethanol: Current Case } \\
\hline & \multicolumn{3}{|c|}{ Dry Milling } & \multicolumn{3}{|c|}{ Wet Milling } \\
\hline Petroleum & $93.3 \%$ & $94.9 \%$ & $94.7 \%$ & $90.2 \%$ & $91.9 \%$ & $91.8 \%$ \\
\hline GHG emissions & $19.2 \%$ & $23.8 \%$ & $26.9 \%$ & $12.4 \%$ & $17.3 \%$ & $20.7 \%$ \\
\hline Fossil energy & $40.3 \%$ & $44.4 \%$ & $46.5 \%$ & $39.5 \%$ & $43.6 \%$ & $45.7 \%$ \\
\hline \multicolumn{7}{|c|}{ Corn-Based Ethanol: Near-Future Case } \\
\hline & \multicolumn{3}{|c|}{ Dry Milling } & \multicolumn{3}{|c|}{ Wet Milling } \\
\hline Petroleum & $93.7 \%$ & $95.8 \%$ & $95.2 \%$ & $91.2 \%$ & $93.5 \%$ & $93.0 \%$ \\
\hline GHG emissions & $26.4 \%$ & $32.3 \%$ & $34.6 \%$ & $24.1 \%$ & $30.1 \%$ & $32.5 \%$ \\
\hline Fossil energy & $46.4 \%$ & $51.7 \%$ & $53.0 \%$ & $48.7 \%$ & $53.8 \%$ & $55.1 \%$ \\
\hline \multicolumn{7}{|c|}{ Cellulosic Ethanol: Near-Future Case } \\
\hline & \multicolumn{3}{|c|}{ Woody Biomass } & \multicolumn{3}{|c|}{ Herbaceous Biomass } \\
\hline Petroleum & $85.5 \%$ & $88.2 \%$ & $87.9 \%$ & $88.0 \%$ & $90.5 \%$ & $90.1 \%$ \\
\hline GHG emissions & $130.6 \%$ & $129.7 \%$ & $127.6 \%$ & $83.6 \%$ & $85.7 \%$ & $85.6 \%$ \\
\hline Fossil energy & $98.3 \%$ & $100.2 \%$ & $99.4 \%$ & $86.6 \%$ & $89.3 \%$ & $88.9 \%$ \\
\hline \multicolumn{7}{|c|}{ Cellulosic Ethanol: Future Case } \\
\hline & \multicolumn{3}{|c|}{ Woody Biomass } & \multicolumn{3}{|c|}{ Herbaceous Biomass } \\
\hline Petroleum & $106.3 \%$ & $90.4 \%$ & $89.8 \%$ & $108.3 \%$ & $92.2 \%$ & $91.5 \%$ \\
\hline GHG emissions & $143.8 \%$ & $115.4 \%$ & $113.5 \%$ & $112.0 \%$ & $85.6 \%$ & $85.1 \%$ \\
\hline Fossil energy & $125.5 \%$ & $94.5 \%$ & $93.5 \%$ & $120.1 \%$ & $89.5 \%$ & $88.7 \%$ \\
\hline
\end{tabular}

The results listed in Tables 8 and 9 show that using a gallon of ethanol, regardless of the blend mix, achieves large emissions and energy use benefits, although the benefits are enhanced slightly for the more efficient vehicle/fuel technologies using E85 and E95. The differences among the per-gallon-of-ethanol results for ethanol in each of the three blends, as shown in the tables, are caused primarily by the fuel economy differences of the vehicles fueled by E10, E85, and E95 (Table 5 lists fuel economy improvements).

Caution must be taken in interpreting the results in Tables 8 and 9. Although use of ethanol in each of three ethanol blends achieves similar reductions in GHG emissions and energy use, achieving the same results requires using different volumes of the three blends. In particular, use of $1 \mathrm{gal}$ of ethanol requires $10 \mathrm{gal}$ of E10, $1.18 \mathrm{gal}$ of E85, or $1.05 \mathrm{gal}$ of E95. Thus, for the same amount of GHG emissions reduced and energy saved, many more miles must be driven using E10 than E85 or E95.

In the long term, use of E10 provides a more limited ability to take advantage of ethanol to reduce GHG emissions and petroleum use than use of E85 or E95. Although the emissions reduction and energy use benefits under the corn ethanol production case we examined would be achieved by expanding the use of only E10, in the longer term, significant reductions in GHG emissions and petroleum use will be accomplished by use of cellulosic ethanol in either FFVs or dedicatedethanol vehicles. 
Table 9 Sensitivity Analysis: Reductions in GHG Emissions and Energy Use per Gallon of Ethanol in Ethanol Blends (percentage relative to emissions and energy use of gasoline)

\begin{tabular}{|c|c|c|c|c|c|c|}
\hline & E10 & E85 & E95 & E10 & E85 & E95 \\
\hline \multicolumn{7}{|c|}{ Corn-Based Ethanol: Current Case, Market-Value-Based Method } \\
\hline & \multicolumn{3}{|c|}{ Dry Milling } & \multicolumn{3}{|c|}{ Wet Milling } \\
\hline Petroleum & $88.6 \%$ & $90.4 \%$ & $90.3 \%$ & $89.0 \%$ & $90.8 \%$ & $90.7 \%$ \\
\hline GHG emissions & $22.0 \%$ & $26.5 \%$ & $29.4 \%$ & $23.1 \%$ & $27.6 \%$ & $30.4 \%$ \\
\hline Fossil energy & $43.9 \%$ & $47.9 \%$ & $49.7 \%$ & $47.5 \%$ & $51.3 \%$ & $53.0 \%$ \\
\hline \multicolumn{7}{|c|}{ Corn-Based Ethanol: Near-Future Case, Market-Value-Based Method } \\
\hline & \multicolumn{3}{|c|}{ Dry Milling } & \multicolumn{3}{|c|}{ Wet Milling } \\
\hline Petroleum & $89.6 \%$ & $92.0 \%$ & $91.6 \%$ & $90.0 \%$ & $92.4 \%$ & $91.9 \%$ \\
\hline GHG emissions & $29.8 \%$ & $35.4 \%$ & $37.6 \%$ & $32.4 \%$ & $37.9 \%$ & $40.0 \%$ \\
\hline Fossil energy & $50.1 \%$ & $55.1 \%$ & $56.3 \%$ & $54.7 \%$ & $59.5 \%$ & $60.5 \%$ \\
\hline \multicolumn{7}{|c|}{ Cellulosic Ethanol: Near-Future Case, Half of Electricity Credit for Displacement Effect } \\
\hline & \multicolumn{3}{|c|}{ Woody Biomass } & \multicolumn{3}{|c|}{ Herbaceous Biomass } \\
\hline Petroleum & $85.3 \%$ & $88.0 \%$ & $87.7 \%$ & $87.9 \%$ & $90.4 \%$ & $90.0 \%$ \\
\hline GHG emissions & $121.8 \%$ & $121.4 \%$ & $119.7 \%$ & $79.2 \%$ & $81.6 \%$ & $81.7 \%$ \\
\hline Fossil energy & $91.3 \%$ & $93.6 \%$ & $93.1 \%$ & $83.1 \%$ & $86.0 \%$ & $85.8 \%$ \\
\hline \multicolumn{7}{|c|}{ Cellulosic Ethanol: Future Case, Half of Electricity Credit for Displacement Effect } \\
\hline & \multicolumn{3}{|c|}{ Woody Biomass } & \multicolumn{3}{|c|}{ Herbaceous Biomass } \\
\hline Petroleum & $106.2 \%$ & $90.3 \%$ & $89.7 \%$ & $108.3 \%$ & $92.2 \%$ & $91.5 \%$ \\
\hline GHG emissions & $141.2 \%$ & $112.9 \%$ & $111.1 \%$ & $110.6 \%$ & $84.4 \%$ & $83.9 \%$ \\
\hline Fossil energy & $123.2 \%$ & $92.3 \%$ & $91.4 \%$ & $119.0 \%$ & $88.4 \%$ & $87.7 \%$ \\
\hline
\end{tabular}




\section{Section 5 References}

Adler, D., 1997, personal communication, Office of Mobile Sources, U.S. Environmental Protection Agency, Ann Arbor, Mich., Oct.

Berger, L., 1998, personal communication, Department of Animal Sciences, University of Illinois, Urbana-Champaign, Ill., May.

Delucchi, M. A., 1998, personal communication, University of California, Davis, Calif., April 8.

Klopfenstein, T., 1998, personal communication, Animal Science Department, University of Nebraska, Lincoln, Neb., May 19.

Madson, P., 1998, personal communication, Rapheal Katzen International Associates, Inc., Cincinnati, Ohio, May 19.

National Renewable Energy Laboratory, Oak Ridge National Laboratory, and Pacific Northwest Laboratory, 1991, A Comparative Analysis of the Environmental Outputs of Future BiomassEthanol Production Cycles and Crude Oil/Reformulated Gasoline Production Cycles, Appendixes, prepared for U.S. Department of Energy, Office of Transportation Technologies and Office of Planning and Assessment, Golden, Colo., Dec.

Trenkle, A., 1998, personal communication, Animal Science Department, Iowa State University, Ames, Iowa, May 19.

U.S. Environmental Protection Agency, 1998, Draft 1998 Inventory for U.S. Greenhouse Gas Emissions and Sinks (1990-1996), Washington, D.C., May.

Price, M., P. Westcott, P. Riley, and M. Graboski, 1998, The Impact of Increased Corn Demand for Ethanol in Planted Cropland, Office of Energy Policy and New Uses, U.S. Department of Agriculture, Washington, D.C., March.

Walsh, M., 1998, personal communication, Oak Ridge National Laboratory, Oak Ridge, Tenn., Oct.

Wang, M. Q., 1996, GREET 1.0 - Transportation Fuel Cycles Model: Methodology and Use, Center for Transportation Research, Argonne National Laboratory, ANL/ESD-33, Argonne, Ill., June. 
Wang, M.Q., C. L. Saricks, and M. Wu, 1997, Fuel-Cycle Fossil Energy Use and Greenhouse Gas Emissions of Fuel Ethanol Produced from U.S. Midwest Corn, prepared for Illinois Department of Commerce and Community Affairs, Center for Transportation Research, Argonne National Laboratory, Argonne, Ill., Dec.

Wooley, R., 1998, personal communication, National Renewable Energy Laboratory, Golden, Colo., Nov. 
Distribution for ANL/ESD-38

M. Fitzpatrick (1)

M. Hale (3)

G. Griparis (2)

M. Wang (800)
362 Library (1)

ANL-E Library (1)

ANL-W Library (1) 
$\Delta$ 